\title{
Klasifikasi Tekstur Serat Kayu pada Citra Mikroskopik Veneer Memanfaatkan Deep Convolutional Neural Network
}

\author{
Suriani Alamgunawan, Teknologi Informasi Institut Sains dan Teknologi Terpadu Surabaya (iSTTS), \\ Dr. Yosi Kristian,Teknik Informatika Institut Sains dan Teknologi Terpadu Surabaya (iSTTS).
}

\begin{abstract}
Abstrak-Convolutional Neural Network sebagai salah satu metode Deep Learning yang paling sering digunakan dalam klasifikasi, khususnya pada citra. Terkenal dengan kedalaman dan kemampuan dalam menentukan parameter sendiri, yang memungkinkan CNN mampu mengeksplor citra tanpa batas. Tujuan penelitian ini adalah untuk meneliti klasifikasi tekstur serat kayu pada citra mikroskopik veneer dengan CNN. Model CNN akan dibangun menggunakan MBConv dan arsitektur lapisan akan didesain menggunakan EfficientNet. Diharapkan dapat tercapai tingkat akurasi yang tinggi dengan penggunaan jumlah parameter yang sedikit. Dalam penelitian ini akan mendesain empat model arsitektur CNN, yaitu model RGB tanpa contrast stretching, RGB dengan contrast stretching, Grayscale tanpa contrast stretching dan Grayscale dengan contrast stretching. Proses ujicoba akan mencakup proses pelatihan, validasi dan uji pada masing-masing input citra pada setiap model arsitektur. Dengan menggunakan penghitungan softmax sebagai penentu kelas klasifikasi. SGD optimizer digunakan sebagai optimization dengan learning rate 1e-1. Hasil penelitian akan dievaluasi dengan menghitung akurasi dan error dengan menggunakan metode F1-score. Penggunaan channel RGB tanpa contrast stretching sebagai citra input menunjukkan hasil uji coba yang terbaik.
\end{abstract}

Kata Kunci-Contrast Stretching, Convolutional Neural Network, EfficientNet, Grayleveling.

\section{PENDAHULUAN}

K lasifikasi tekstur serat kayu sangat menarik untuk digunakan sebagai bahan penelitian. Veneer sebagai salah satu hasil dari olahan kayu yang banyak digunakan sebagai bahan untuk mempercantik dan memperindah peralatan rumah tangga dan desain interior. Dengan keindahan dan keunikan yang timbul dari serat dan warna kayu asalnya, hal ini membuat veneer mempunyai nilai lebih sebagai komoditas dagang. Seluruh kayu yang ada dapat diolah menjadi veneer, hal ini memberikan nilai tambah sekaligus tingkat kesulitan dalam mengenali jenis kayu. Dikarenakan jenis ragam, warna, tekstur dan arah serat kayu sangat berbengaruh dalam pengenalan veneer. Kemampuan dan pengalaman sangat diperlukan dalam mengenali jenis kayu asal veneer.

Dengan pemanfaatan digital mikroskopik sebagai salah satu media penunjang dalam pencitraan serat kayu pada veneer. Dimana digital mikroskopik digunakan sebagai salah satu alat bantu yang berfungsi unutk mengambil citra serat dengan pembesaran 1000x. Misalnya seperti penelitian yang dilakukan oleh Luiz G. Hafemann [1]dengan menggunakan digital mikroskopik dan penerapan model deep neural network dapat mencapai tingkat akurasi yang tinggi dalam mengklasifikasikan spesies hutan Brasil. Dan digunakan pada penelitian yang dilakukan oleh Jinmei Yang[2] untuk mengklasifikasi, mendeteksi dan mengidentifikasi 25 jenis kayu langka.

Diharapkan dengan penerapan metode klasifikasi berbasis Convolutional Neural Networks dalam perancangan sistem pengklasifikasian jenis kayu pada tekstur serat kayu dengan citra mikroskopis dapat memberikan tingkat akurasi pengklasifikasian di atas $80 \%$.

\section{LANDASAN TEORI}

Gunakan dokumen ini sebagai template agar format paper anda sesuai dengan format paper yang kami perlukan dan ketikan teks anda di dalamnya. Akan tetapi apabila anda ingin melakukan layouting sendiri berikut adalah panduannya.

\section{A. Convolutional Neural Network}

Struktur jaringan CNN[3] pada dasarnya dapat dikelompok menjadi dua tahapan yaitu Feature Learning dan Classification. Dimana dalam tahapan feature learning meliputi Convolutional Layer, Rectified Linear Unit (ReLU) dan Pooling Layer. Sedangkan pada tahapan Classification mengerucut pada proses pengklasifikasian neuron untuk dapat menjadi satu kelas terpilih.

Lapisan feature learning berguna untuk mentransasikan input menjadi sebuah fitur berdasarkan ciri input dalam bentuk angka vector. Kemampuan pembelajaran dari CNN dimulai dengan pembelajaran dalam pengenalan sebuah objek pada beberapa regional, dengan menggunakan sliding window. Proses window ini bergerak dari satu regional ke regional yang lain dengan tujuan untuk mencari aspek yang paling informatif, yang dikenal dengan sebutan filter. Filter yang sama akan bergerak pada beberapa regional yang berbeda.

Setiap pergerakan filter dan input yang bergeser berkali-kali menghasilkan suatu fitur baru sebagai output atau biasa disebut dengan feature map atau activation map. Penghitungan output berdasarkan neuron yang terhubung ke dalam input, dimana masing-masing akan menghitung produk titik (dot function) antara bobot dan wilayah yang 
terhubung dengan volume input. Nilai pixel input citra akan dikalikan dengan nilai pada filter.

Dalam proses konvolusi terdapat beberapa pengaturan yang dapat dilakukan, meliputi ukuran filter, jumlah stride dan penggunaan zero padding. Filter size ditentukan tergantung pada berapa banyak aspek informative yang ingin ditangkap saat proses pengolahan sebuah regional.

\section{B. Fungsi Aktivasi}

Fungsi aktivasi merupakan bagian penting dalam sebuah jaringan neural network yang tidak dapat kita lewatkan. Dimana fungsi aktivasi berperan penting untuk membuat sebuah jaringan neural menjadi non-linear. Terdapat banyak fungsi aktivasi yang dapat digunakan dalam model, setiap fungsi aktivasi memiliki kekurang dan kelebihan masingmasing. Fungsi aktivasi yang akan dibahas adalah ReLU (Rectified Linear Unit), Sigmoid dan ReLu6.

ReLU (Rectified Linear Unit). ReLU akan menghilangkan vanishing gradient dengan cara penerapan fungsi aktivasi elemen. Aktivasi elemen akan dilakukan dengan membuat pembatas pada bilangan nol, artinya apabila $x \leq 0$ maka $x=0$ dan apabila $x>0$ maka $x=x$.

$f(x)=\max (0, x)$

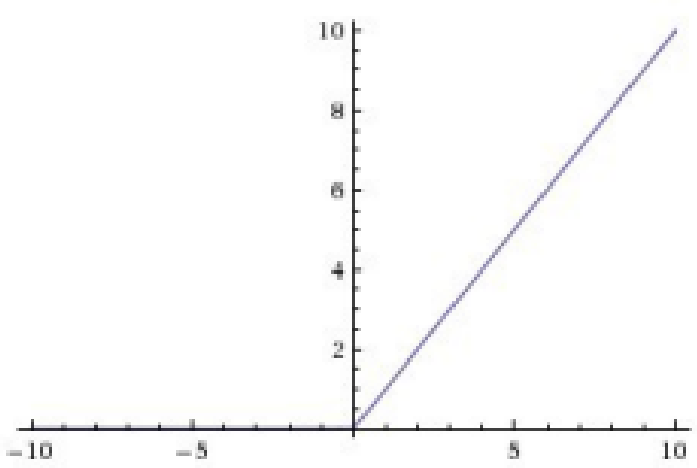

Gambar 1 . Rectified Linear Unit (ReLU)

Sigmoid adalah fungsi aktivasi yang akan mengubah angka menjadi non-linear dengan rentang nilai dari 0 sampai 1 . Sigmoid mulai jarang digunakan dikarenakan sigmoid akan mematikan gradient, di saat aktivasi neuron mengeluarkan nilai yang berada pada akhir 0 atau 1, maka gradient di rentangan ini bernilai hampir 0 . Dikarenakan gradient memiliki nilai sangat kecil, sigmoid akan mematikan gradient. Selain itu output sigmoid tidak zero-centered, yang berdampak pada ketidakdinamisan gradient descent. Jika data selalu positif maka gradient pada weights selama backpropagation menjadi semua positif atau semua negatif.

ReLU6 [4] adalah pengembangan dari ReLU, dimana ReLU mempunyai rentangan $(0, x)$, yang artinya apabila $x \leq$ 0 maka $x=0$ dan apabila $x>0$ maka $x=x$. Hal ini berarti nilai $x$ bisa tidak terbatas, yang berakibat kepada membengkaknya nilai aktivasi. Solusinya adalah dengan menetapkan nila $x$ dengan angka terntentu. Angka yang digunakan adalah 6 , maka fungsi aktivasi menjadi:

$y=\min (\max (x, 0), 6)$

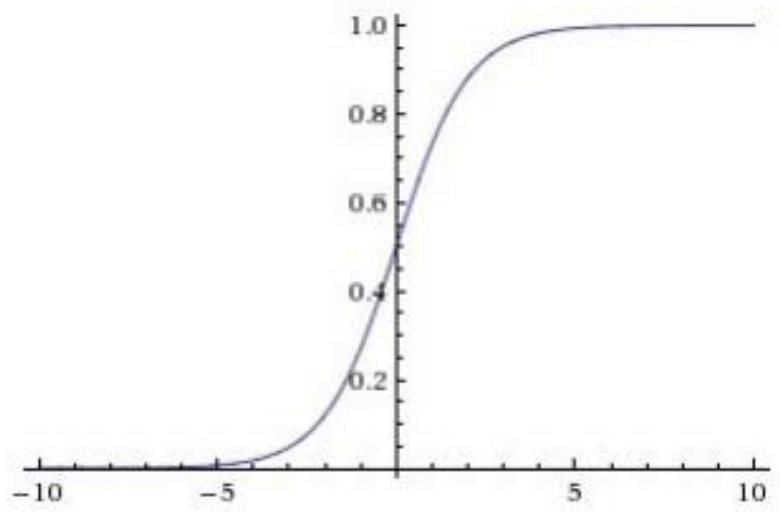

Gambar 2. Sigmoid

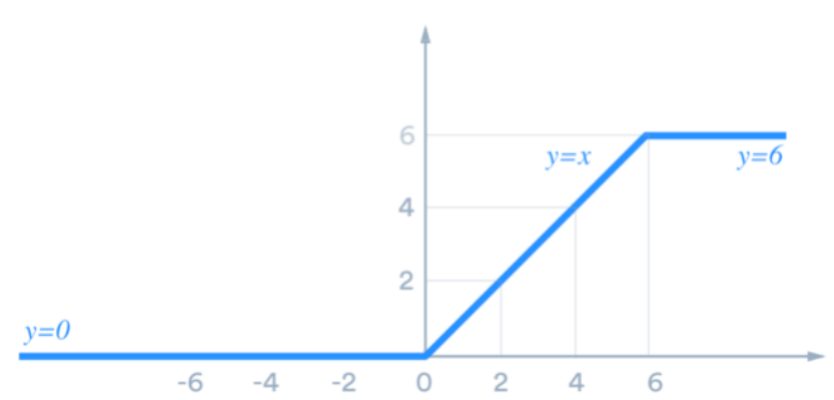

Gambar 3. ReLU6

\section{Pooling Layer}

Lapisan pooling merupakan lapisan yang berfungsi sebagai untuk memperkecil dimensi dari citra. Dikarenakan tahapan ini merupakan downsampling sehingga memperkecil parameter, maka kecepatan komputasi dapat lebih meningkat. Metode Pooling yang paling sering digunakan adalah Max Pooling dan Average Pooling. Max Pooling menentukan nilai maksimum, sedangkan Average Pooling menentukan nilai rata-rata. Max Pooling lebih banyak digunakan karena dengan max pooling filter dapat mengeksplorasi nilai tertinggi pada citra. Sedangkan Average Pooling mencari nilai rata-rata pada tiap dimensi.

\section{Evaluasi Hasil}

Evaluasi hasil uji coba dilakukan dengan mengukur nilai precision, recall dan F-1 Score. Precision (P) adalah perbandingan antara nilai True Possitive (TP) dengan total data yang diprediksi positif. Recall (R) adalah perbandingan antara nilai True Possitive (TP) dengan total data yang sebenarnya positif. F-1 Score adalah metode yang menyeimbangkan antara Precision dan Recall, dimana nilai terbaik adalah 1 dan nilai terburuk adalah 0. Nilai F-1 Score yang baik menunjukkan bahwa model klasifikasi memiliki nilai precision dan recall yang baik.

$P=\frac{T P}{T P+F P}$

$R=\frac{T P}{T P+F N}$

$F 1=2 \frac{P R}{P+R}$ 


\section{METODE PENELITIAN}

Metode penelitian yang digunakan dalam proses pengklasifikasian tekstur serat kayu veneer pada citra mikroskopis, meliputi dataset yang akan digunakan, metode klasifikasi, dan arsitektur CNN yang akan disusun.

\section{A. Dataset}

Dataset yang digunakan berupa image mikroskopis atas veneer, yang diperoleh dengan mengumpulkan fisik veneer sesuai dengan jenis kelas yang akan menjadi output. Setelah fisik veneer terkumpul maka veneer akan diambil citranya menggunakan digital mikroskopis. Jumlah dataset yang digunakan untuk penelitian total sebanyak 9.144 citra. Adapun pembagian penggunaan dataset dalam penelitian ini adalah $60 \%$ untuk proses training, $20 \%$ proses validasi dan $20 \%$ proses testing.

Citra yang berhasil dikumpulkan per kelas terdiri dari kelas Sungkai sebanyak 804 citra, kelas Mahoni sebanyak 792 citra, kelas Eboni sebanyak 828 citra, kelas Mindi sebanyak 684 citra, kelas Sengin sebanyak 492 citra, kelas Mangga sebanyak 840 citra, kelas Ceri sebanyak 1.500 citra, kelas Walnut sebanyak 1.056 citra, kelas Keruing sebanyak 828 citra, dan kelas Jati Kampung sebanyak 1.320.
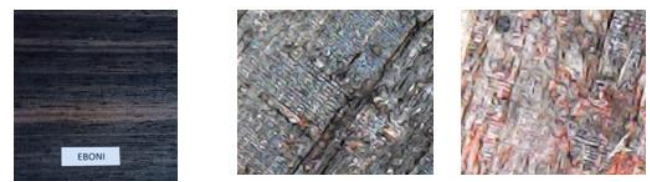

Gambar 4. Contoh fisik veneer dan citra mikroskopik

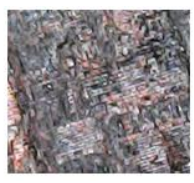

\section{B. Metode Klasifikasi}

Metode klasifikasi yang digunakan adalah convolutional neural network dengan model arsitektur yang dibangun menggunakan pendekatan Mobile Inverted Bottleneck Conv (MBConv) Block[5] dan dibuat menyerupai EfficientNet[6][7]

Alasan penggunaan layer dan block untuk meningkatkan performa efektivitas dan efisiensi dari sebuah arsitektur jaringan neural. Dengan mampu meningkatkan pencapaian tingkat akurasi lebih tinggi dengan jumlah paramaeter yang relatif lebih sedikit, ringan untuk dapat diimplementasikan dan secara otomatis meningkatkan kecepatan. Tingkat akurasi merupakan alasan yang terpenting dan paling utama dalam penyusunan neural network.

Penerapan Squeeze and Excitation (SE) Block[8][9] dan Mobile Inverted Bottleneck Conv (MBConv) Block[10][10] telah terbukti dapat mempengaruhi tingkat akurasi dengan jumlah parameter yang minimal, yang memungkinkan pengaplikasian di desktop, laptop dan mobile devices.

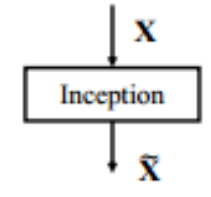

Inception Module

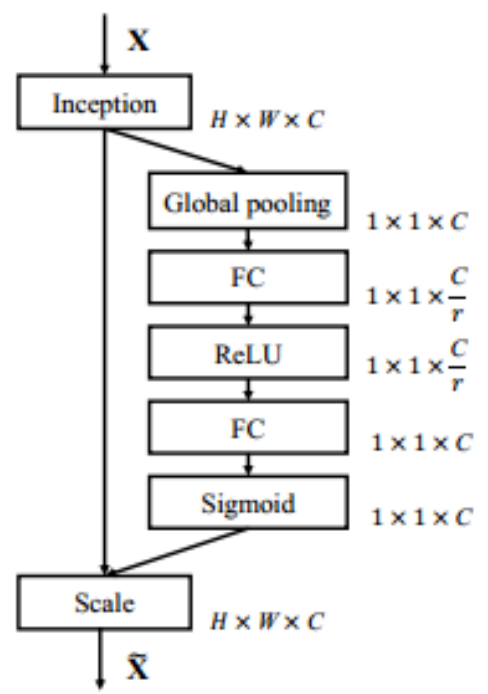

Gambar 5. SE - Inception Module

\section{Arsitektur CNN}

Model struktur arsitektur CNN pada penelitian ini terlihat pada tabel I, yang menampilkan jumlah lapisan CNN yang akan dijalankan sebelum akhirnya menuju pada proses penentuan klasifikasi dari masing-masing kelas dengan metode softmax.

TABEL I

\section{MODEL STRUKTUR ARSITEKTUR CNN}

\begin{tabular}{|c|c|c|c|c|c|c|}
\hline Layer & $\begin{array}{l}\mathrm{C} \text { (Total Filter) } \\
\text { (T) }\end{array}$ & Stride & $\mathbf{R}$ & Padding & Input & Output \\
\hline Conv2D 3x3 & 32 & 2 & - & Same & $128 \mathrm{X} 128 \mathrm{X} 3$ & $64 \times 64 \times 32$ \\
\hline MBCConv3 (k5x5) & 16 & 1 & 2 & - & $64 \times 64 \times 32$ & $64 \times 64 \times 16$ \\
\hline MBCConv6 (k3x3) & 32 & 1 & - & - & $64 \times 64 \times 16$ & $64 \times 64 \times 32$ \\
\hline MBCConv3 (k5x5) & 48 & 2 & 4 & - & $64 \times 64 \times 32$ & $32 \times 32 \times 48$ \\
\hline MBCConv3 (k3x3) & 64 & 1 & 4 & - & $32 \times 32 \times 48$ & $32 \times 32 \times 64$ \\
\hline MBCConv3 (k3x3) & 80 & 2 & 4 & - & $32 \times 32 \times 64$ & $16 \times 16 \times 80$ \\
\hline MBCConv3 (k5x5) & 96 & 1 & 6 & - & $16 \times 16 \times 80$ & $16 \times 16 \times 96$ \\
\hline MBCConv3 (k5x5) & 112 & 2 & 6 & - & $16 \times 16 \times 96$ & $8 \times 8 \times 112$ \\
\hline MBCConv3 (k3×3) & 128 & 1 & 6 & - & $8 \times 8 \times 112$ & $8 \times 8 \times 128$ \\
\hline MBCConv6 (k5x5) & 140 & 2 & - & - & $8 \times 8 \times 128$ & $4 \times 4 \times 140$ \\
\hline Conv2D $1 \times 1$ & 256 & 1 & - & Valid & $4 \times 4 \times 140$ & $4 \times 4 \times 256$ \\
\hline Swish & - & - & - & - & $4 \times 4 \times 256$ & $4 \times 4 \times 256$ \\
\hline Global Average Pooling & - & - & - & - & $4 \times 4 \times 256$ & 256 \\
\hline Fully Connected & 256 & - & - & - & 256 & 256 \\
\hline ReLU6 & - & - & - & - & 256 & 256 \\
\hline Global Average Pooling & 100 & - & - & - & 256 & 100 \\
\hline Softmax & 10 & - & - & - & 100 & 10 \\
\hline
\end{tabular}

Terdapat 11 lapisan pada convolutional layer dan 2 fully connected, sebelum data dimasukkan ke dalam proses penentuan kelas.

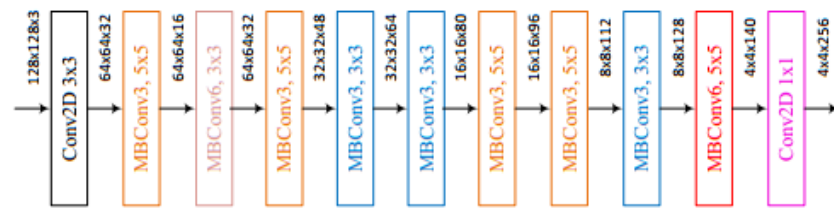

Gambar 6. EfficientNet yang disusun

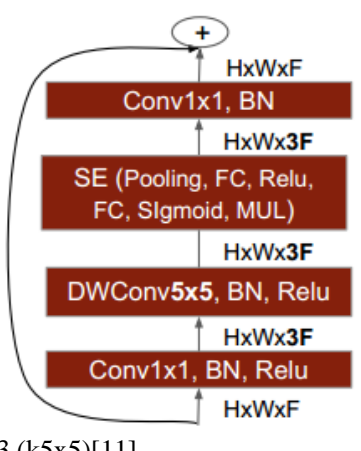

Gambar 7. MBConv3 (k5x5)[11] 


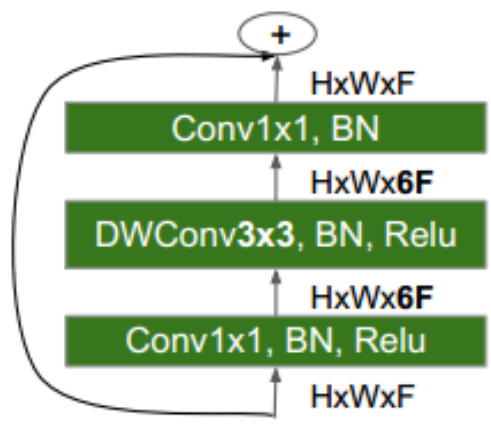

Gambar 8. MBConv6 (k3x3)[11]

\section{Alur Penelitian}

Alur penelitian dalam penelitian ini dapat dilihat pada gambar 9, dimana terdapat empat proses uji coba sesuai dengan model penelitian yang sudah ditetapkan.

Penelitian RGB tanpa contrast stretching, dalam penelitian ini menggunakan input citra mikroskopis veneer 3 channel (RGB) tanpa melalui proses contrast stretching sebelum masuk dalam model CNN. Penelitian RGB dengan contrast stretching, Penelitian ini menggunakan input citra mikroskopis veneer 3 channel (RGB) dan melalui proses contrast stretching sebelum masuk dalam model CNN.

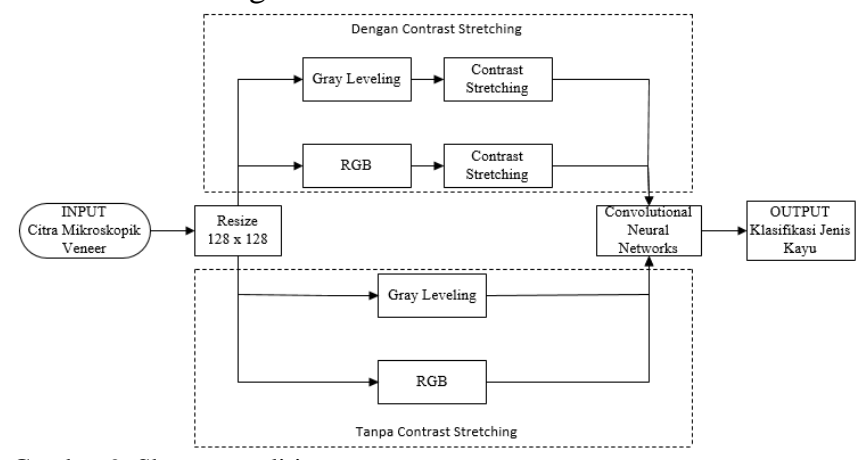

Gambar 9. Skema penelitian

Penelitian grayscale tanpa contrast stretching, dalam penelitian ini menggunakan input citra mikroskopis veneer satu channel (Grayscale) tanpa contrast stretching sebelum masuk dalam model CNN. Penelitian grayscale dengan contrast stretching, Penelitian ini menggunakan input citra mikroskopis veneer satu channel (Grayscale) dan melalui proses contrast stretching.

\section{HASIL UJI COBA}

Hasil uji coba yang dilakukan dalam mengevaluasi semua model yang telah disusun dalam penelitian ini dalam mengklasifikasikan tekstur serat kayu pada citra mikroskopis veneer. Hasil uji coba akan dijelaskan secara runtut hasil training yang diperoleh mulai dari model RGB tanpa contrast stretching, RGB dengan contrast stretching, Grayscale tanpa contrast stretching dan Grayscale dengan contrast stretching.

\section{A. RGB tanpa Contrast Stretching}

Hasil uji coba klasifikasi tekstur serat kayu pada citra mikroskopis pada veneer dengan menggunakan model arsitektur CNN atas input dataset RGB tanpa contrast stretching, menunjukkan nilai F-1 score sebesar 0.97 dengan Precission sebesar 0.96 dan Recall sebesar 0.97.

TABEL II

HASIL TRAINING RGB TANPA CONTRAST STRETCHING

\begin{tabular}{lrrrr}
\hline \multirow{2}{*}{ KELAS } & \multicolumn{4}{c}{ GRAYSCALE - STRETCH } \\
& Precision & Recall & F1-Score & Support \\
\hline Sungkai & 0.71 & 0.75 & 0.73 & 161 \\
Mahoni & 0.74 & 0.89 & 0.81 & 158 \\
Eboni & 0.88 & 0.97 & 0.92 & 166 \\
Mindi & 0.69 & 0.58 & 0.63 & 137 \\
Sengon & 0.66 & 0.93 & 0.77 & 98 \\
Mangga & 0.92 & 0.65 & 0.77 & 168 \\
Ceri & 0.80 & 0.78 & 0.79 & 300 \\
Walnut & 0.62 & 0.83 & 0.71 & 211 \\
Keruing & 0.72 & 0.38 & 0.50 & 166 \\
Jati Kampung & 0.74 & 0.70 & 0.72 & 264 \\
& & & & 1,829 \\
\hline
\end{tabular}

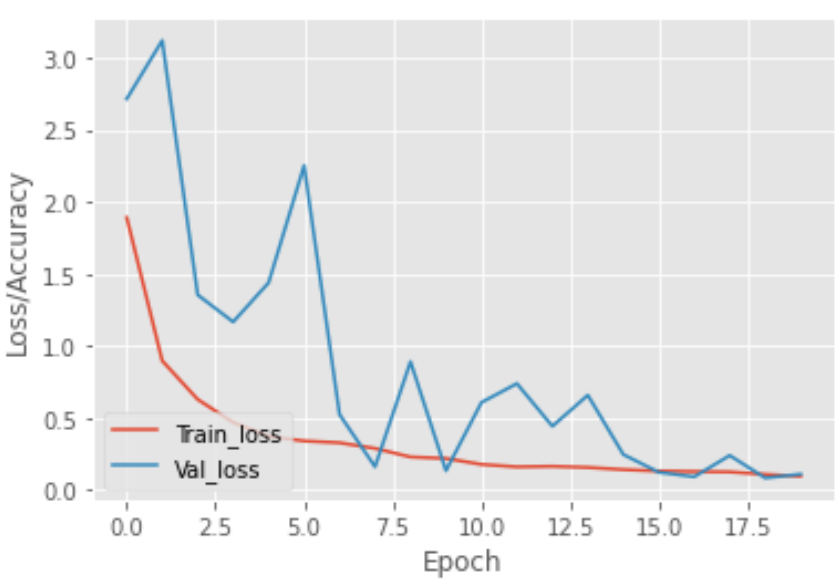

Gambar 10. Grafik loss/accuracy RGB tanpa contrast stretching

\section{B. RGB dengan Contrast Stretching}

Hasil uji coba klasifikasi tekstur serat kayu pada citra mikroskopis pada veneer dengan menggunakan model arsitektur CNN atas input dataset RGB dengan contrast stretching, menunjukkan nilai F-1 score sebesar 0.94 dengan Precission sebesar 0.93 dan Recall sebesar 0.93.

TABEL III

HASIL TRAINING RGB DENGAN CONTRAST STRETCHING

\begin{tabular}{lrrrr}
\multicolumn{1}{c}{ KELAS } & \multicolumn{4}{c}{ RGB - STRETCH } \\
& Precision & Recall & F1-Score & Support \\
\hline Sungkai & 0.93 & 0.99 & 0.96 & 161 \\
Mahoni & 0.99 & 0.96 & 0.97 & 158 \\
Eboni & 0.93 & 0.98 & 0.95 & 166 \\
Mindi & 0.94 & 0.77 & 0.84 & 137 \\
Sengon & 1.00 & 0.95 & 0.97 & 98 \\
Mangga & 0.94 & 0.96 & 0.95 & 168 \\
Ceri & 0.92 & 0.90 & 0.91 & 300 \\
Walnut & 0.97 & 0.93 & 0.95 & 211 \\
Keruing & 0.81 & 0.96 & 0.88 & 166 \\
Jati Kampung & 0.95 & 0.94 & 0.95 & 264 \\
& & & & 1,829 \\
\hline
\end{tabular}




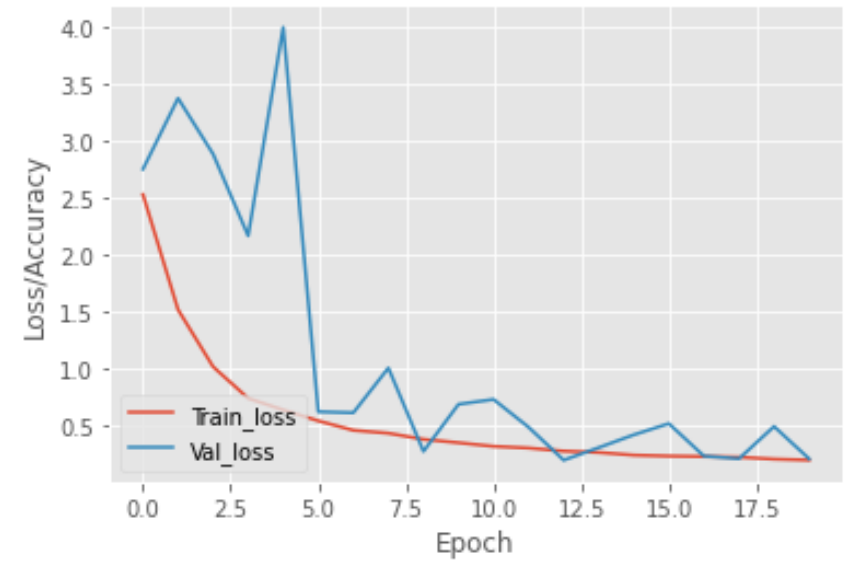

Gambar 11. Grafik loss/accuracy RGB dengan contrast stretching

\section{Grayscale tanpa Contrast Stretching}

Hasil uji coba klasifikasi tekstur serat kayu pada citra mikroskopis pada veneer dengan menggunakan model arsitektur CNN atas input dataset grayscale tanpa contrast stretching, menunjukkan nilai F-1 score sebesar 0.91 dengan Precission sebesar 0.91 dan Recall sebesar 0.90.

TABEL IV

HASIL TRAINING GRAYSCALE TANPA CONTRAST STRETCHING

\begin{tabular}{lrrrr}
\hline \multicolumn{1}{c}{ KELAS } & \multicolumn{4}{c}{ GRAYSCALE - NO STRETCH } \\
& Precision & Recall & F1-Score & Support \\
\hline Sungkai & 0.82 & 0.99 & 0.94 & 161 \\
Mahoni & 0.89 & 0.99 & 0.94 & 158 \\
Eboni & 0.86 & 1.00 & 0.93 & 166 \\
Mindi & 0.76 & 0.95 & 0.84 & 137 \\
Sengon & 1.00 & 0.84 & 0.91 & 98 \\
Mangga & 1.00 & 0.80 & 0.89 & 168 \\
Ceri & 0.94 & 0.91 & 0.93 & 300 \\
Walnut & 0.94 & 0.89 & 0.91 & 211 \\
Keruing & 0.92 & 0.92 & 0.92 & 166 \\
Jati Kampung & 0.95 & 0.80 & 0.87 & 264 \\
& & & & 1,829 \\
\hline
\end{tabular}

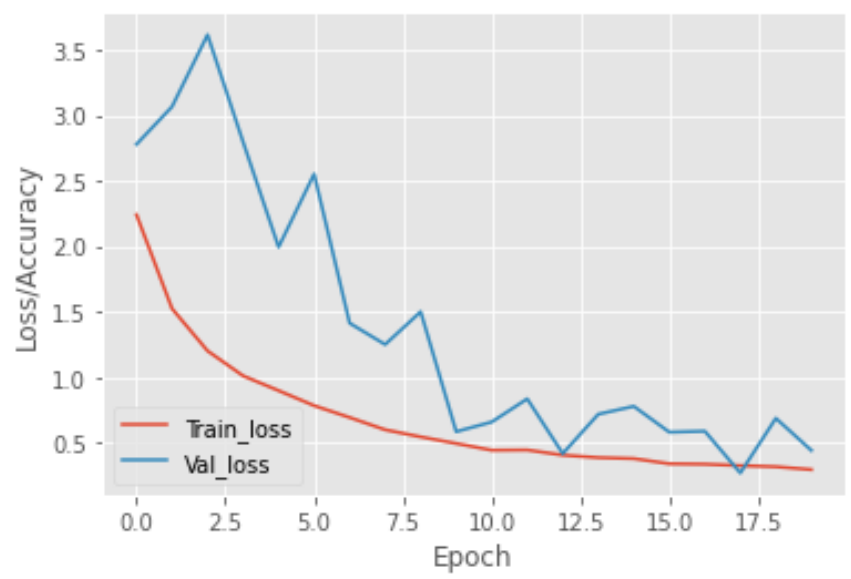

Gambar 12. Grafik loss/accuracy grayscale tanpa contrast stretching

\section{Grayscale dengan Contrast Stretching}

Hasil uji coba klasifikasi tekstur serat kayu pada citra mikroskopis pada veneer dengan menggunakan model arsitektur CNN atas input dataset grayscale dengan contrast stretching, menunjukkan nilai F-1 score sebesar 0.75 dengan
Precission sebesar 0.75 dan Recall sebesar 0.74 .

TABEL V

HASIL TRAINING GRAYSCALE DENGAN CONTRAST STRETCHING

\begin{tabular}{lrrrr}
\hline \multirow{2}{*}{ KELAS } & \multicolumn{4}{c}{ GRAYSCALE - STRETCH } \\
& Precision & Recall & F1-Score & Support \\
\hline Sungkai & 0.71 & 0.75 & 0.73 & 161 \\
Mahoni & 0.74 & 0.89 & 0.81 & 158 \\
Eboni & 0.88 & 0.97 & 0.92 & 166 \\
Mindi & 0.69 & 0.58 & 0.63 & 137 \\
Sengon & 0.66 & 0.93 & 0.77 & 98 \\
Mangga & 0.92 & 0.65 & 0.77 & 168 \\
Ceri & 0.80 & 0.78 & 0.79 & 300 \\
Walnut & 0.62 & 0.83 & 0.71 & 211 \\
Keruing & 0.72 & 0.38 & 0.50 & 166 \\
Jati Kampung & 0.74 & 0.70 & 0.72 & 264 \\
& & & & 1,829 \\
\hline
\end{tabular}

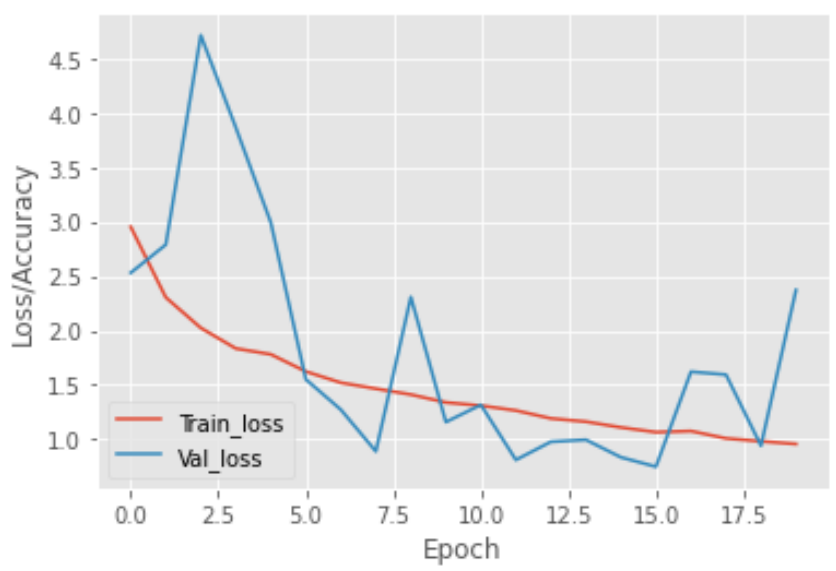

Gambar 13. Grafik loss/accuracy grayscale dengan contrast stretching

\section{KESIMPULAN}

Penelitian ini membuktikan bahwa kemampuan penerapan Convolutional Neural Network untuk memecahkan permasalahan dalam bidang citra. Model yang disusun dalam penelitian ini mampu menghasilkan tingkat akurasi dalam mengklasifikasikan tekstur serat kayu dalam citra mikroskopik pada veneer sebesar $>=80 \%$.

Dari hasil uji coba atas 4 model arsitektur yang disusun, yaitu model RGB tanpa contrast stretching, RGB dengan contrast stretching, Grayscale tanpa contrast stretching dan Grayscale dengan contrast strectching. Model RGB tanpa contrast stretching mampu memberikan tingkat akurasi paling tinggi yaitu sebesar 0.97. Disusul berikut nya oleh model RGB dengan contrast stretching sebesar 0.93, model Grayscale tanpa contrast stretching sebesar 0.90 dan terakhir model Grayscale dengan contrast stretching sebesar 0.74 .

Dari hasil uji coba menunjukkan bahwa data input dalam bentuk warna (RGB) mempunyai peran penting terhadap pencapaian hasil training dan hasil testing yang lebih bagus, baik atas pencapaian nilai precission, recall maupun tingkat akurasi.

Penerapan contrast stretching tidak cocok digunakan dalam klasifikasi tekstur serat kayu pada citra mikroskopik veneer. Penggunaan contrast stretching menurunkan kinerja model dalam mencapai akurasi. Dimana pada setiap model 
dalam penelitian yang menggunakan contrast stretching justru mengalami penurunan tingkat akurasi. Hal ini terbukti dengan menurunnya tingkat akurasi sebesar 0.04 untuk RGB dan 0.16 untuk grayscale.

Meskipun data input dalam bentuk RGB mampu memberikan hasil yang lebih baik, di lain sisi data input dalam bentuk RGB memerlukan waktu training yang lebih lama yaitu sebanyak rata-rata 2 detik per epoch.

\section{DAFTAR PUSTAKA}

[1] L. G. Hafemann, L. S. Oliveira, and P. Cavalin, "Forest species recognition using deep convolutional neural networks," 2014, doi: 10.1109/ICPR.2014.199.

[2] J. Yang, P. Huang, F. Dai, Y. Sun, L. Wang, and H. Bi, "Application of Deep Learning in Wood Classification," 2019 IEEE Int. Conf. Comput. Sci. Educ. Informatiz. CSEI 2019, pp. 124-129, 2019, doi: 10.1109/CSEI47661.2019.8938960.

[3] I. MathWorks, "Convolutional Neural Network - MATLAB \& Simulink." p. 1.

[4] C. Doshi, "Why Relu? Tips for using Relu. Comparison between Relu, Leaky Relu, and Relu-6.," pp. 2-7, 2019.

[5] M. Sandler, A. Howard, M. Zhu, A. Zhmoginov, and L. C. Chen, "MobileNetV2: Inverted Residuals and Linear Bottlenecks," Proc. IEEE Comput. Soc. Conf. Comput. Vis. Pattern Recognit., pp. 4510-4520, 2018, doi: 10.1109/CVPR.2018.00474.

[6] M. Tan and Q. V. Le, "EfficientNet: Rethinking model scaling for convolutional neural networks," 36th Int. Conf. Mach. Learn. ICML 2019, vol. 2019-June, pp. 10691-10700, 2019.

[7] M. Tan, "Blog AutoML and Model Scaling," pp. 1-4, 2019.

[8] J. Hu, "Squeeze-andExcitation_Networks_CVPR_2018_paper.pdf," Cvpr, pp. 71327141, $201 \overline{8}$.

[9] K. Ta and P. Follow, "Squeeze and Excitation Networks ( Hu et al .," pp. 3-6, 2020.

[10] A. Howard et al., "Searching for mobileNetV3," Proc. IEEE Int Conf. Comput. Vis., vol. 2019-October, pp. 1314-1324, 2019, doi: 10.1109/ICCV.2019.00140.

[11] M. Tan et al., "Mnasnet: Platform-aware neural architecture search for mobile," Proc. IEEE Comput. Soc. Conf. Comput. Vis. Pattern Recognit., vol. 2019-June, pp. 2815-2823, 2019, doi: 10.1109/CVPR.2019.00293. 